\title{
Article \\ A Descriptive Cohort of Suicidal Cancer Patients: Analysis of the Autopsy Case Series from 1993 to 2019 in Milan (Italy)
}

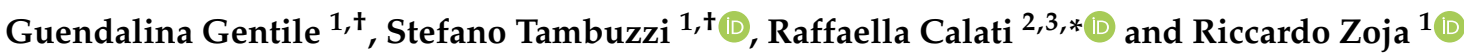 \\ 1 Department of Biomedical Sciences for Health, Section of Legal Medicine and Insurance, University of Milan, \\ 20133 Milan, Italy; guendalina.gentile@unimi.it (G.G.); stefano.tambuzzi@unimi.it (S.T.); \\ riccardo.zoia@unimi.it (R.Z.) \\ 2 Department of Psychology, University of Milan-Bicocca, 20126 Milan, Italy \\ 3 Department of Adult Psychiatry, Nimes University Hospital, 30029 Nimes, France \\ * Correspondence: raffaella.calati@unimib.it \\ + These authors contributed equally to this work.
}

check for

updates

Citation: Gentile, G.; Tambuzzi, S.; Calati, R.; Zoja, R. A Descriptive Cohort of Suicidal Cancer Patients: Analysis of the Autopsy Case Series from 1993 to 2019 in Milan (Italy). Int. J. Environ. Res. Public Health 2022, 19, 829. https://doi.org/ 10.3390/ijerph19020829

Academic Editor:

Paul B. Tchounwou

Received: 17 November 2021

Accepted: 4 January 2022

Published: 12 January 2022

Publisher's Note: MDPI stays neutral with regard to jurisdictional claims in published maps and institutional affiliations.

Copyright: (c) 2022 by the authors. Licensee MDPI, Basel, Switzerland. This article is an open access article distributed under the terms and conditions of the Creative Commons Attribution (CC BY) license (https:// creativecommons.org/licenses/by/ $4.0 /)$.

\begin{abstract}
Suicide in cancer patients has always been a subject of clinical studies, but the contribution of forensic pathology to this phenomenon is poorly reported. With the aim of at least partially filling this gap in information, at the Institute of Forensic Medicine of Milan, Italy, we assessed all suicides that occurred in cancer patients. A descriptive and retrospective analysis was carried out by examining the database of the Institute and autopsy reports. We included 288 suicide cases with proven cancer diseases. For each suicide, sex, age, country of origin, body area affected by cancer, further pathological history, medications, previous suicide attempts and suicidal communications, as well as the place where the suicide occurred, were assessed. Furthermore, from a forensic point of view, we considered the chosen suicide method and any involved means. The majority of cases were male older adults affected by lung, colon and prostate cancer. Violent suicide methods were prevalent, and the most represented suicide method was falling from height regardless of the body area affected by cancer. Such data may be of clinical use for clinicians engaged in the front lines in order to address suicide risk prevention strategies among cancer patients.
\end{abstract}

Keywords: suicide; cancer; depression; oncology; mental health; autopsy

\section{Introduction}

The World Health Organization (WHO) has estimated that 700,000 people die by suicide every year in the world [1] and that cancer globally causes approximately 10 million decedents [2]. A malignant tumor diagnosis can also be a stressor that may increase the likelihood of suicide [3-5]. In cancer patients, the risk of suicide is up to double compared to the one of the general population in the United States, Europe, Australia, Taiwan and South Korea [6,7]. Moreover, the risk is at its highest during the first months and, in any case, in the first year after diagnosis [8] or, at most, within two years [9]. An important role is played by the anatomical localization of the neoplasm $[5,10,11]$; indeed, tumors located in the head and neck [12] and those arising in the digestive tract (especially in the esophagus, pancreas and stomach) [13], as well as those affecting lungs [14] and prostate [15], are associated with higher rates of suicide [16]. The incidence increases in older adults [17], as well as in subjects in the progression or terminal phase of cancer [18]. The increase in suicide risk is more pronounced for men [19,20] than for women [21], especially when older than 54 years old [6], suffering from depression [22] and in the case of malignant neoplastic disease with poor prognosis [23]. Women, on the other hand, when affected by neoplasms localized in gynecological areas, show a higher incidence of suicide than those affected by tumors localized in other anatomical sites [24].

Although the overall cancer survival rates thanks to the progress of screening and treatment have improved [25] in Italy [26] and globally [5], cancer diagnosis [27], due to 
the emotional shock and upheaval that it causes or the progression of the disease [28], can represent a risk factor for suicide [6]. Indeed, numerous population studies around the world [21] have already established, over the last years [29], an increase in suicide rates in cancer patients [30], especially if depressed [22,31]. Consequently, the phenomenon of suicide in cancer patients is the subject of many studies, but the contribution of forensic pathology is poorly represented so far [3,14,32-36]. In particular, suicide methods of cancer patients and the site of the neoplasm have not yet been explored. Such information, however, being able to be obtained exclusively by using an autopsy approach, would inevitably be compromised or lost without an autopsy. Therefore, the privileged position from which a forensic pathologist works allows exploring, in depth, not only the causes of death but also the methods of suicide in cancer patients.

With the aim of filling at least part of this gap, we conducted a descriptive analysis of the characteristics of suicides occurring in subjects with malignant neoplasia whose autopsies were performed at the Institute of Forensic Medicine in Milan, Italy, between 1993 and 2019. The data that emerged from this cross-section of reality can both help forensic pathologists to address the often-challenging cases of suicide in cancer patients and be useful to clinicians engaged on the front lines to address suicide risk prevention strategies among cancer patients.

\section{Materials and Methods}

A descriptive and retrospective analysis was carried out on all 25,512 autopsies performed between 1993 and 2019 by using the database of the Institute of Forensic Medicine in Milan and autopsy reports (a copy of which is stored in the archives). To enroll the cases of our interest, we considered the following inclusion criteria: (i) subjects that underwent an autopsy; (ii) subjects with a proven malignant oncological pathology, based on the information available from clinical records seized by the Judicial Authority and still in our possession, as well as written in the farewell notes left behind by the decedents or reported by their family members during body identification; (iii) subjects that were aware of being affected by a cancer. With respect to the cause of death of each subject, we referred to the death certificate completed by the forensic pathologist at the end of the autopsy. We excluded all decedents that were affected from dementia, always based on the clinical records, or for whom the cancer diagnosis was not certain, as well as all cases in which a neoplastic lesion was detected for the first time during the autopsy. For each enrolled subject, we extracted the following information: sex, age, country of origin, location of cancer, further pathological history, medications, previous suicide attempts, and suicidal communications (threats and plans), as well as the location of the suicide. All data collected were analyzed using descriptive statistics.

Furthermore, from a forensic point of view, we considered includible as suicides all cases in which circumstantial information (suicidal communications and farewell notes), police reports and autopsy evidence were consistent and converging towards a deliberately self-induced death. For all enrolled cases, we carefully assessed the suicide methods chosen by the victims and the involved means, if present. According to the methods used, suicide was classified as violent (hanging, stabbing, shooting, jumping from buildings or in front of vehicles, severe deliberate car accident, electricity and fire) or non-violent (illicit or prescription drug overdoses, CO-intoxication, plastic bag suffocation and drowning) [37,38]. Furthermore, based on the number of detrimental modalities involved in the suicide, we distinguished simple suicides (only one modality) from complex and complicated suicides. In the forensic literature, complex suicides refer to highly uncommon suicides in which multiple detrimental methods are used simultaneously or in chronological succession to avoid possible ineffectiveness of one of the chosen methods and achieving a guaranteed fatal outcome [39-41]. On the other hand, the term "complicated suicide" refers to a suicide in which the method established by the victim fails, but death still occurs due to an accidental secondary trauma that was not planned $[42,43]$. As for complex and complicated suicides, the distinction between violent and non-violent suicides is based on the first 
detrimental modality that was chosen and applied. During all autopsies, biological fluids (heart and femoral blood, urine, bile and gastric contents) and organ fragments (brain, lung, liver and kidney) were sampled from bodies for possible toxicological analyzes. In Italy, the analysis of cadaveric samples can be carried out only with the expressed authorization of the investigating magistrate for each individual case. In this study, all enrolled cases for which toxicological analyses were authorized were performed at the Forensic Toxicology laboratory of the University of Milan in order to detect ethyl alcohol, drugs and any other substance with pharmacological activity.

\section{Results}

\subsection{Socio-Demographic Features}

In the analyzed period of time, 4,498 suicides occurred (17.6\% of all the autopsies) and, among them, 288 were subjects with diagnosed malignant neoplasm $(6.40 \%$ of all suicide cases and $1.2 \%$ of total autopsies).

Males were involved globally in 200 cases (69.4\% of the total), with a sex ratio of 2.3:1.

For a description of the age distribution of the sample according to sex, refer to Figure 1. For males, the maximum and minimum age range was 28-94 years old, with mean of 69.27 and median of 73; for females, the maximum and minimum age range was $25-93$ years old, with mean of 63.97 and median of 66. No victims were recorded under the age of 24 . The youngest victim was a 25-year-old girl. The majority of the sample was represented by older adults: $32 \%$ of cases were $71-80$-year-old (93 cases), $22 \%$ were $61-70$ year old (65 cases) and 17\% were 81-90 year old (49 cases). The older case was a 94-year-old man.

\section{Suicide cancer population divided by age according to sex}

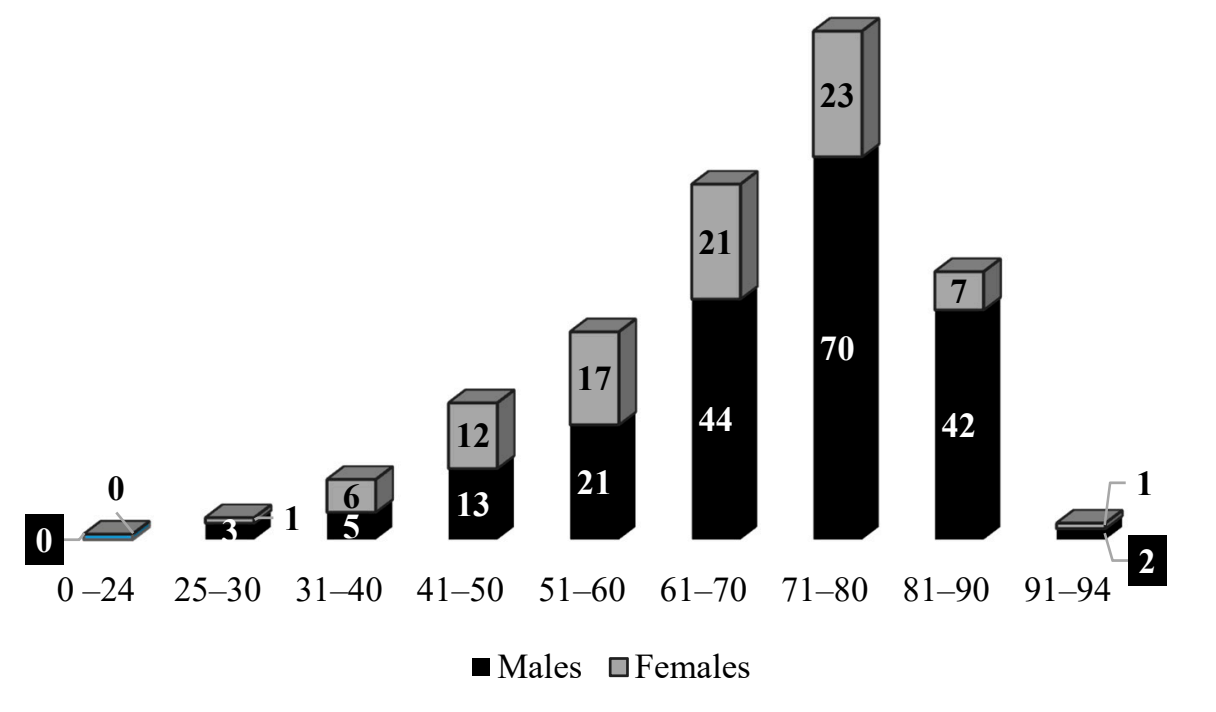

Figure 1. Graphic representation of the subjects died by suicide affected with cancer divided by sex and age decades.

Cases were mainly of Italian origins (283, 98.3\%), three were white Europeans (Spanish, Albanian, Norwegian), one was Asiatic (Malaysian) and one was black African (Somalian). All such five decedents had been living in Italy for at least 5 years.

\subsection{Cancer-Related Features}

For a detailed description of prevalent neoplastic sites according also to sex, refer to Table 1. Malignant neoplasms observed in the enrolled victims involved the following body areas: head $(n=14,4.9 \%)$, with the prevalence of brain cancer; neck $(n=23,8 \%)$, 
with the prevalence of laryngeal cancer; chest $(n=73,25.3 \%)$, with the prevalence of lung cancer; abdomen $(n=78,27.1 \%)$, with the prevalence of colon cancer; reproductive system $(n=56,19.4 \%)$, with the prevalence of prostate cancer; urinary system $(n=22,7.7 \%)$, with the prevalence of bladder cancer; immune system $(n=16,5.6 \%)$; integumentary system $(n=5,1.7 \%)$, skeletal system $(1,0.3 \%)$. In males, main neoplastic sites involved lung and prostate, colon, larynx and bladder; on the other hand, in females, breast, uterus and colon were the main neoplastic sites.

Table 1. Details by anatomical district of the prevalent neoplastic sites according to the victim's sex.

\begin{tabular}{|c|c|c|c|c|}
\hline \multirow{2}{*}{ Body Area } & \multirow{2}{*}{ Site } & \multirow{2}{*}{ Total (\%) } & \multicolumn{2}{|c|}{ Sex } \\
\hline & & & M (\%) & F (\%) \\
\hline \multirow{3}{*}{$\begin{array}{c}\text { Head } \\
14(4.9 \%)\end{array}$} & Brain & $9(64.3)$ & $5(55.5)$ & $4(44.5)$ \\
\hline & Ear & $1(7.1)$ & $1(100)$ & \\
\hline & Tongue & $4(28.6)$ & $3(75)$ & $1(25)$ \\
\hline \multirow{3}{*}{$\begin{array}{c}\text { Neck } \\
23(8 \%)\end{array}$} & Pharynx & $2(8.8)$ & $2(100)$ & \\
\hline & Thyroid & $6(26)$ & $2(33.3)$ & $4(66.7)$ \\
\hline & Larynx & $15(65.2)$ & $14(93.3)$ & $1(6.7)$ \\
\hline \multirow{3}{*}{$\begin{array}{c}\text { Chest } \\
73(25.3 \%)\end{array}$} & Esophagus & $4(5.5)$ & $4(100)$ & \\
\hline & Breast & $29(39.7)$ & & $29(100)$ \\
\hline & Lung & $40(54.8)$ & $36(90)$ & $4(10)$ \\
\hline \multirow{8}{*}{$\begin{array}{l}\text { Abdomen } \\
78(27.1 \%)\end{array}$} & Liver & $11(14.1)$ & $7(63.6)$ & $4(36.4)$ \\
\hline & Biliary tract & $4(5.1)$ & $4(100)$ & \\
\hline & Pancreas & 13 (16.7) & $10(77)$ & $3(33)$ \\
\hline & Stomach & 12 (15.3) & $11(91.6)$ & $1(8.4)$ \\
\hline & Duodenum & $1(1.4)$ & $1(100)$ & \\
\hline & Colon & $26(33.3)$ & $16(61.5)$ & $10(38.4)$ \\
\hline & Rectum & $9(11.6)$ & $6(66.6)$ & $3(33.4)$ \\
\hline & Peritoneum & $2(2.5)$ & $2(100)$ & \\
\hline \multirow{4}{*}{$\begin{array}{l}\text { Reproductive system } \\
56(19.4 \%)\end{array}$} & Testicle & $5(8.9)$ & $5(100)$ & \\
\hline & Prostate & $36(64.3)$ & $36(100)$ & \\
\hline & Ovary & $3(5.3)$ & & $3(100)$ \\
\hline & Uterus & $12(21.5)$ & & $12(100)$ \\
\hline Urinary system & Kidney & $10(45.5)$ & $7(70)$ & $3(30)$ \\
\hline $22(7.7 \%)$ & Bladder & $12(54.5)$ & 11 (91.6) & $1(8.4)$ \\
\hline $\begin{array}{c}\text { Immune system } \\
16(5.5 \%)\end{array}$ & Lymphocytes & $16(100)$ & $12(75)$ & $4(25)$ \\
\hline $\begin{array}{l}\text { Integumentary system } \\
5(1.7 \%)\end{array}$ & Skin & $5(100)$ & $5(100)$ & \\
\hline $\begin{array}{l}\text { Skeletal system } \\
1(0.3 \%)\end{array}$ & Bone & $1(100)$ & $1(100)$ & \\
\hline
\end{tabular}

With respect to the correspondence between the site of the neoplasm and the victims' decade of age, it was observed that half of the younger decedents (25-30-years-olds, mean age of 28 years old) had testicular cancer. Furthermore, lung cancer prevailed among $31-40$-year-old decedents (27.3\%, mean age of 36 years old); breast cancer and immune system cancers prevailed among 41-50-year-old decedents (respectively, 20\%, mean age of 47.4 years old, and $16 \%$, mean age of 44.6 years old); breast cancer and lung cancer prevailed among 51-60-year-old decedents (respectively, 21\%, mean age of 54.6 years old, and $13 \%$, mean age of 59 years old), as well as among 61-70-year-old ones (respectively, in $15.4 \%$, mean age of 65.9 years old, and $13.4 \%$, mean age of 64.9 years old). Prostate cancer and lung cancer prevailed among 71-80-year-old decedents (respectively, 18.3\%, mean age of 76.5 years old, and $16.1 \%$, mean age of 75.4 years old); finally, among 81-90year-old decedents, prostate cancer $(28.6 \%$, mean age of 85.2 years old) and colon and 
bladder cancer $(12.3 \%$ each, respectively, with mean age of 85.2 years old and 84.5 years old) prevailed.

Furthermore, in 17 cases (6\% out of the total), the existence of distant metastasis was reported, starting from a primary tumor localized to lung, prostate and colon (three cases-17.6\% for each); larynx and liver (two cases- $11.8 \%$ for each); and testicle, tongue, skin and bladder (one case- $-5.9 \%$ for each).

\subsection{Clinical Features}

In addition to malignant neoplasm, 185 victims (64\%) had a further positive medical history consisting of a single disease in 139 cases (75\%) and multiple diseases in 46 cases $(25 \%)$, the details of which are shown in Table 2.

Table 2. Details of single and multiple disease affecting victims.

\begin{tabular}{|c|c|c|c|c|c|}
\hline \multicolumn{2}{|c|}{ Type of Pathology } & Disease 1 & Disease 2 & $N$ of Cases & $\%$ \\
\hline \multirow{7}{*}{$\begin{array}{c}\text { Single } \\
\text { disease-139 }\end{array}$} & Psychiatric & \multicolumn{2}{|c|}{ Depression } & 109 & 98.1 \\
\hline & $111(79.8 \%)$ & \multicolumn{2}{|c|}{ Psychosis } & 2 & 1.9 \\
\hline & \multirow{5}{*}{$\begin{array}{c}\text { Organic } \\
28(20.2 \%)\end{array}$} & \multicolumn{2}{|c|}{ Hypertension } & 9 & 32.1 \\
\hline & & \multirow{2}{*}{\multicolumn{2}{|c|}{ Myocardial infarction }} & 8 & 28.5 \\
\hline & & & & 2 & 7.2 \\
\hline & & \multicolumn{2}{|c|}{$\begin{array}{c}\text { Coronary artery disease } \\
\text { Diabetes }\end{array}$} & 7 & 25 \\
\hline & & \multicolumn{2}{|c|}{ Hepatitis c virus (HCV) } & 2 & 7.2 \\
\hline \multirow{22}{*}{$\begin{array}{c}\text { Multiple } \\
\text { diseases-46 }\end{array}$} & \multirow{14}{*}{$\begin{array}{c}\text { Psychiatric } \\
37(80.4 \%)\end{array}$} & \multirow{14}{*}{$\begin{array}{c}\text { Depression } \\
37(100 \%)\end{array}$} & Alcoholism & 8 & 21.7 \\
\hline & & & $\mathrm{HCV}$ & 4 & 10.8 \\
\hline & & & Myocardial infarction & 4 & 10.8 \\
\hline & & & Hypertension & 4 & 10.8 \\
\hline & & & Diabetes & 3 & 8.1 \\
\hline & & & Arrhythmia & 3 & 8.1 \\
\hline & & & Bronchial asthma & 2 & 5.4 \\
\hline & & & Kidney failure & 2 & 5.4 \\
\hline & & & Maculopathy & 2 & 5.4 \\
\hline & & & Epilepsy & 1 & 2.7 \\
\hline & & & Cerebral stroke & 1 & 2.7 \\
\hline & & & Parkinson disease & 1 & 2.7 \\
\hline & & & Pulmonary emphysema & 1 & 2.7 \\
\hline & & & Sarcoidosis & 1 & 2.7 \\
\hline & \multirow{8}{*}{$\begin{array}{l}\text { Organic } \\
9(19.6)\end{array}$} & \multirow{3}{*}{$\begin{array}{c}\text { COPD } \\
\text { (chronic obstructive } \\
\text { pulmonary disease) } \\
4(44.4 \%)\end{array}$} & Hypertension & 2 & 50 \\
\hline & & & $\mathrm{HCV}$ & 1 & 25 \\
\hline & & & Heart failure & 1 & 25 \\
\hline & & \multirow{5}{*}{$\begin{array}{l}\text { Hypertension } \\
5(55.6)\end{array}$} & Aortic aneurysm & 1 & 20 \\
\hline & & & Diabetes & 1 & 20 \\
\hline & & & Epilepsy & 1 & 20 \\
\hline & & & Glaucoma & 1 & 20 \\
\hline & & & Neuropathy & 1 & 20 \\
\hline
\end{tabular}

It is clear that, in the group of a single disease, psychiatric disorders were the most prevalent, followed by organic diseases, such as cardiovascular pathologies, diabetes and chronic infections (HCV). Moreover, in the group of multiple diseases, psychiatric disorders resulted to be the most represented, since they affected the vast majority of subjects; They were associated with chronic cardiovascular, respiratory, renal and nervous diseases. Other victims did not suffer from psychiatric disorders but a combination of organic diseases, such as respiratory diseases and chronic cardiovascular or neurological pathologies. Overall, the subjects affected by depression were 146 ( $51 \%$ of the total).

Out of a total of all victims with a positive medical history, 201 (70\%) were undergoing pharmacological treatment. On the whole, 89 subjects $(44.2 \%)$ were taking drugs for psychiatric pathologies, and, among them, 67 decedents $(75.2 \%)$ were taking therapy for depression; 68 (33.8\%) were undergoing specific pharmacological treatment for cancer with chemotherapy. Furthermore, 133 (66\%) subjects were taking only one medication, and $68(34 \%)$ were taking multi-drug therapy. In the first group, chemotherapy was clearly the most frequently observed medication (44 cases-33\%) followed by antidepressants 
(38 cases-28.6\%); the detail of the remaining drugs taken as monotherapy is reported in Table 3. In the second group, the most frequently reported medications were antidepressants (29 cases-43\%), chemotherapy (18 cases-26.5\%), analgesics (8 cases-12\%), diuretics (6 cases-8.8\%), anxiolytics (5 cases-7.4\%) and antihypertensives ( 2 cases-3\%); the details of the multi-drug medications are reported in Table 3. As far as it is known, 68 subjects were, therefore, under chemotherapy treatment at the time of suicide. However, for subjects off therapy, the time elapsed from the off-therapy period to suicide was not available.

Table 3. Medications taken by the enrolled victims. In A, details of single-drug therapy; in B, details of multi-drug therapy.

(A)

\begin{tabular}{|c|c|c|c|}
\hline & Medication & & $N$ of Cases $(\%)$ \\
\hline \multicolumn{2}{|c|}{ Single-drug therapy-133-66\% } & $\begin{array}{c}\text { Chemotherapy } \\
\text { Antidepressants } \\
\text { Anxiolytics } \\
\text { Antihypertensive } \\
\text { Analgesic } \\
\text { Antiepileptic } \\
\text { Oxygen therapy } \\
\text { Antipsychotics } \\
\text { Proton-pump inhibitor } \\
\text { Antithyroid } \\
\text { Antiparkinsonian } \\
\text { Antiplatelets agents } \\
\text { Oral hypoglycemic agents } \\
\text { Anti-inflammatory } \\
\text { Diuretics } \\
\text { Blood products }\end{array}$ & $\begin{array}{l}44(33) \\
38(28.7) \\
12(9) \\
5(3.8) \\
8(6) \\
2(1.5) \\
1(0.7) \\
4(3) \\
2(1.5) \\
3(2.3) \\
1(0.7) \\
3(2.3) \\
3(2.3) \\
4(3) \\
2(1.5) \\
1(0.7)\end{array}$ \\
\hline \multicolumn{4}{|c|}{ (B) } \\
\hline & Medication & & $N$ of Cases $(\%)$ \\
\hline \multirow{6}{*}{ Multi-drug therapy-68-34\% } & $\begin{array}{c}\text { Antidepressants } \\
29(42.7 \%)\end{array}$ & $\begin{array}{c}\text { Chemotherapy } \\
\text { Anxiolytics } \\
\text { Antihypertensive } \\
\text { Morphine } \\
\text { Immunosuppressants } \\
\text { Antiarrhythmic } \\
\text { Antiepileptic }\end{array}$ & $\begin{array}{c}6(20.6) \\
13(44.8) \\
4(13.8) \\
3(10.3) \\
1(3.5) \\
1(3.5) \\
1(3.5)\end{array}$ \\
\hline & $\begin{array}{c}\text { Chemotherapy } \\
18(26.5 \%)\end{array}$ & $\begin{array}{c}\text { Morphine } \\
\text { Antihypertensive } \\
\text { Insulin } \\
\text { Cortisone } \\
\text { Diuretics } \\
\text { Antiemetics } \\
\text { Interferon } \\
\text { Oral hypoglycemic agents }\end{array}$ & $\begin{array}{l}5(27.7) \\
4(22.2) \\
2(11.2) \\
2(11.2) \\
1(5.5) \\
2(11.2) \\
1(5.5) \\
1(5.5)\end{array}$ \\
\hline & $\begin{array}{l}\text { Analgesic } \\
8(11.8 \%)\end{array}$ & $\begin{array}{l}\text { Antiplatelets agents } \\
\text { Cortisone } \\
\text { Diuretics } \\
\text { Proton-pump inhibitor }\end{array}$ & $\begin{array}{l}3(37.5) \\
2(25) \\
2(25) \\
1(12.5)\end{array}$ \\
\hline & $\begin{array}{l}\text { Diuretics } \\
6(8.8 \%)\end{array}$ & $\begin{array}{c}\text { Cardiotonic } \\
\text { Oral hypoglycemic agents } \\
\text { Antiepileptic } \\
\text { Anxiolytics } \\
\text { Antiplatelets agents }\end{array}$ & $\begin{array}{l}2(33.6) \\
1(16.6) \\
1(16.6) \\
1(16.6) \\
1(16.6)\end{array}$ \\
\hline & $\begin{array}{c}\text { Anxiolytics } \\
5(7.3 \%)\end{array}$ & $\begin{array}{c}\text { Cortisone } \\
\text { Sedative-hypnotic }\end{array}$ & $\begin{array}{l}1(20) \\
4(80)\end{array}$ \\
\hline & $\begin{array}{c}\text { Antihypertensive } \\
2(2.9 \%)\end{array}$ & $\begin{array}{l}\text { Antiplatelets agents } \\
\text { Cortisone }\end{array}$ & $\begin{array}{l}1(50) \\
1(50)\end{array}$ \\
\hline
\end{tabular}




\subsection{Suicide-Related Features}

Of the 288 enrolled cases, 119 subjects $(41.3 \%)$ had previously communicated that they wanted to die by suicide, 48 subjects $(16.5 \%)$ had made previous suicide attempts and $42(14.6 \%)$ had adopted both behaviors. The main reasons reported in the farewell notes or by the relatives for the suicide were the poor efficacy of the medical treatments $(n=134)$, serious side effects of therapies $(n=236)$, the worsening of the quality of life $(n=263)$, derived surgical complications $(n=57)$, insufficient pain management $(n=123)$, the progression of the disease $(n=191)$, poor prognosis $(n=245)$ and, ultimately, related physical deteriorations $(n=251)$. As expected, there were often multiple coexistent reasons behind the decision to die from suicide.

The majority of suicide cases $(n=283,98.3 \%)$ used a single suicide method and the minority used two different methods simultaneously or in a chronological sequence $(n=4,1.4 \%)$, carrying out a complex suicide. In detail, complex suicides involved only male subjects and consisted of the following: hanging and plastic bag suffocation; hanging and gunshot wound; sharp injuries and plastic bag suffocation; and sharp injuries and falling from a height, in one case each. A complicated suicide occurred in only one case $(0.3 \%)$, which was accomplished by failed hanging followed by a fall from height.

A violent suicide was present in 251 cases (246 simple, 4 complex and 1 complicated suicide) for a total of $87 \%$, while a non-violent suicide was recorded in 37 cases (all simple suicides) for a total of $13 \%$ (Table 4$)$. In detail, 181 males (72\%) and 70 females (28\%) were involved in violent suicide; on the other hand, 19 males (51.5\%) and 18 females (48.5\%) were involved in non-violent suicide.

With respect to toxicological analysis, they were authorized by the investigating magistrates in 169 cases. In 60 subjects (35.5\%), the blood alcohol level (BAC) was found between 0.1 and $0.8 \mathrm{~g} / \mathrm{L}$. The dosage of carboxyhemoglobin $(\mathrm{HbCO})$ was required for all six victims who died of suicide through carbon monoxide inhalation, and in all such cases the concentrations of $\mathrm{HbCO}$ higher than 33\% were measured in their heart blood. In the literature, this value is considered as a threshold for acute and potentially lethal $\mathrm{CO}$ intoxication [44]. Regarding illicit drugs, only four victims tested positive for cannabinoids. Finally, traces of caffeine and cotinine were identified in 103 victims.

Overall, in all 288 cases, a cause of death was determined, also thanks to the performance of lab analyses. Thus, in no case was the cause of death undetermined, similarly to what normally occurs in all suicide cases that undergo autopsy.

Finally, we also analyzed the location where suicides took place. It was observed that $66 \%$ of such events occurred in the victims' house, followed by $30 \%$ of cases by outdoor locations, among which the hospital courtyard and urban streets were the most prevalent; the remaining $4 \%$ of victims died by suicide in closed places outside their houses, especially in hospital rooms (Figure 2).

To better understand the phenomenon of suicide in cancer patients by using forensic data, we have briefly related prevalent neoplastic sites to detrimental modalities applied to death by suicide, maintaining the distinction between males and females (Table 5). 
Table 4. Details of violent and non-violent suicides.

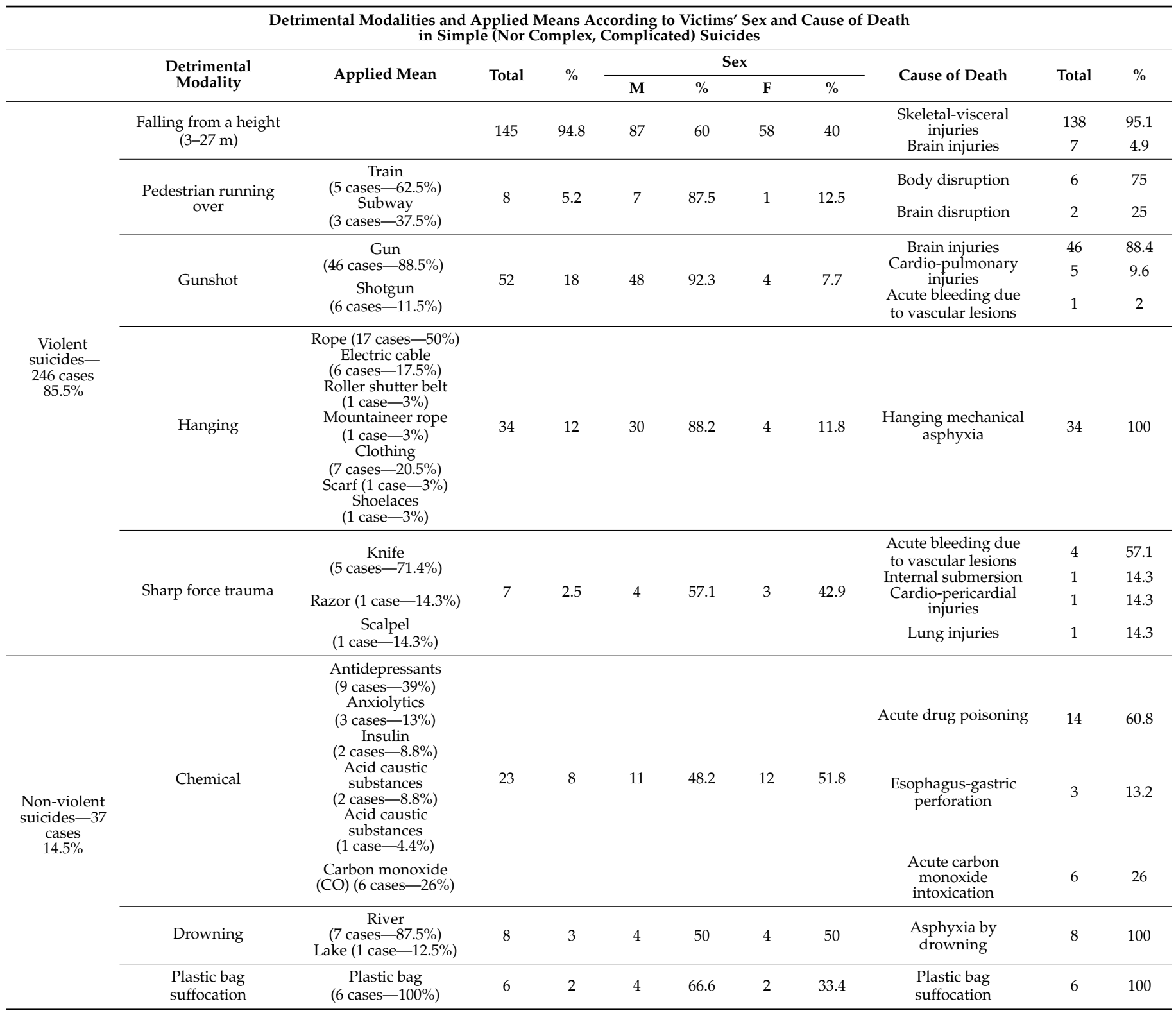

\begin{tabular}{|cc|}
\hline Hospital courtyard & 30 \\
\hline Urban street & 27 \\
\hline Car & 9 \\
\hline River or Canal & 7 \\
\hline Railway track & 5 \\
\hline Field & 4 \\
\hline Underground & 3 \\
\hline Lake & 1 \\
\hline
\end{tabular}

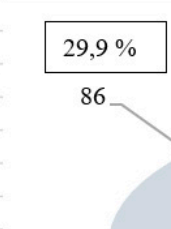

Place of suicide
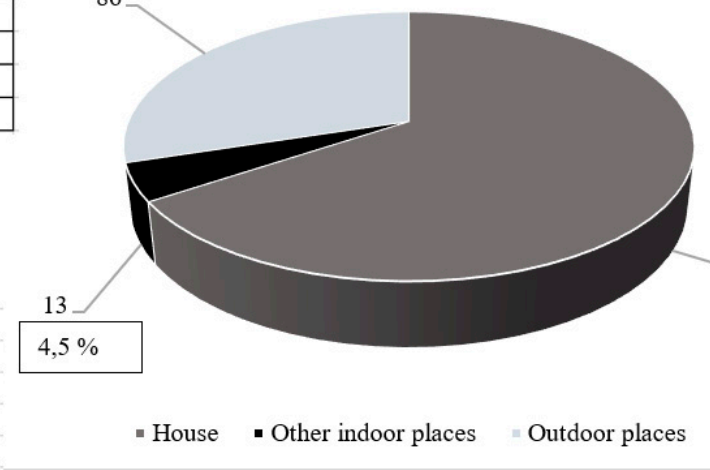

\begin{tabular}{|cc|}
\hline House's garden & 86 \\
\hline Bedroom & 58 \\
\hline Bathroom & 12 \\
\hline Kitchen & 8 \\
\hline Garage & 7 \\
\hline Cellar & 6 \\
\hline Stairs & 5 \\
\hline Balcony & 4 \\
\hline Livingroom & 2 \\
\hline Attic & 1 \\
\hline
\end{tabular}

\begin{tabular}{|cl|}
\hline Hotel & 3 \\
\hline Office & 2 \\
\hline Hospital room & 6 \\
\hline Supermarket & 1 \\
\hline Factory & 1 \\
\hline
\end{tabular}

House - Other indoor places

Figure 2. Graphic representation of locations where suicides occurred. 
Table 5. Breakdown of victims based on sex, tumor site and applied detrimental suicide modality.

\begin{tabular}{|c|c|c|c|c|c|c|c|c|c|c|c|c|c|c|c|c|c|c|c|c|c|}
\hline \multirow{3}{*}{ Body Area } & \multirow{3}{*}{ Site } & \multicolumn{10}{|c|}{ Violent Suicide } & \multicolumn{6}{|c|}{ Non-Violent Suicide } & & & & \\
\hline & & \multicolumn{2}{|c|}{$\begin{array}{l}\text { Falling } \\
\text { from a } \\
\text { Height }\end{array}$} & \multicolumn{2}{|c|}{$\begin{array}{l}\text { Pedestrian } \\
\text { Run } \\
\text { over }\end{array}$} & \multicolumn{2}{|c|}{ Gunshot } & \multicolumn{2}{|c|}{ Hanging } & \multicolumn{2}{|c|}{$\begin{array}{l}\text { Sharp } \\
\text { Force } \\
\text { Trauma }\end{array}$} & \multicolumn{2}{|c|}{ Chemical } & \multicolumn{2}{|c|}{ Drowning } & \multicolumn{2}{|c|}{$\begin{array}{l}\text { Plastic } \\
\text { Bag Suf- } \\
\text { focation }\end{array}$} & \multicolumn{2}{|c|}{$\begin{array}{l}\text { Complex } \\
\text { Suicide }\end{array}$} & \multicolumn{2}{|c|}{$\begin{array}{l}\text { Complicated } \\
\text { Suicide }\end{array}$} \\
\hline & & $\mathbf{M}$ & $F$ & $\mathbf{M}$ & F & $\mathbf{M}$ & $\mathbf{F}$ & $\mathbf{M}$ & $\mathbf{F}$ & $\mathbf{M}$ & $\mathbf{F}$ & $\mathbf{M}$ & $F$ & $\mathbf{M}$ & $F$ & $\mathbf{M}$ & $F$ & $\mathbf{M}$ & $\mathbf{F}$ & $\mathbf{M}$ & $F$ \\
\hline \multirow{2}{*}{ Head } & $\begin{array}{c}\text { Brain } \\
\text { Ear }\end{array}$ & 2 & 3 & & & $\begin{array}{l}2 \\
1\end{array}$ & & 1 & & & & & & & 1 & & & & & & \\
\hline & Tongue & & 1 & & & 1 & & & & & & & & & & & & 1 & & 1 & \\
\hline \multirow{3}{*}{ Neck } & Pharynx & & & & & 2 & & & & & & & & & & & & & & & \\
\hline & Thyroid & 1 & 3 & & & & & & & & & & 1 & & 1 & & & & & & \\
\hline & Larynx & 6 & 1 & & & 4 & & 2 & & & & & & & & 2 & & & & & \\
\hline \multirow{3}{*}{ Chest } & Esophagus & 2 & & & & 2 & & & & & & & & & & & & & & & \\
\hline & Breast & & 18 & & & & 1 & & 3 & & & & 4 & & 1 & & 2 & & & & \\
\hline & Lung & 18 & 3 & 1 & & 9 & & 5 & & 2 & 1 & 1 & & & & & & & & & \\
\hline \multirow{8}{*}{ Abdomen } & Liver & 6 & 2 & & & & 1 & & & & & & 1 & & & & & 1 & & & \\
\hline & Biliary tract & 4 & & & & & & & & & & & & & & & & & & & \\
\hline & Pancreas & 6 & 1 & & & 2 & & 2 & & & & & 2 & & & & & & & & \\
\hline & Stomach & 7 & 1 & & & 1 & & 2 & & & & & & 1 & & & & & & & \\
\hline & Duodenum & 1 & & & & & & & & & & & & & & & & & & & \\
\hline & Colon & 7 & 9 & & & 1 & & 5 & & & 1 & 2 & & 1 & & & & & & & \\
\hline & Rectum & 1 & 2 & 1 & & 1 & 1 & 3 & & & & & & & & & & & & & \\
\hline & Peritoneum & 2 & & & & & & & & & & & & & & & & & & & \\
\hline \multirow{3}{*}{$\begin{array}{l}\text { Reproductive } \\
\text { System }\end{array}$} & Testicle & & & 1 & & 1 & & 1 & & & & 2 & & & & & & & & & \\
\hline & Prostate & 11 & & 2 & & 12 & & 4 & & 2 & & 2 & & & & 2 & & 1 & & & \\
\hline & $\begin{array}{l}\text { Ovary } \\
\text { Uterus }\end{array}$ & & $\begin{array}{l}3 \\
9\end{array}$ & & & & & & & & & & 2 & & 1 & & & & & & \\
\hline Urinary & Kidney & 3 & & & 1 & 1 & 1 & 1 & 1 & & & 1 & & 1 & & & & & & & \\
\hline System & Bladder & 4 & 1 & 1 & & 3 & & 2 & & & & 1 & & & & & & & & & \\
\hline $\begin{array}{l}\text { Immune } \\
\text { System }\end{array}$ & Lymphocytes & 4 & 1 & 1 & & 5 & & & & & 1 & 1 & 2 & & & & & 1 & & & \\
\hline $\begin{array}{l}\text { Integumentary } \\
\text { System }\end{array}$ & Skin & 2 & & & & 1 & & 2 & & & & & & & & & & & & & \\
\hline $\begin{array}{l}\text { Skeletal } \\
\text { System }\end{array}$ & Bone & 1 & & & & & & & & & & & & & & & & & & & \\
\hline
\end{tabular}

\section{Discussion}

We performed a descriptive and retrospective post-mortem analysis on suicides in subjects suffering from a malignant neoplasm $(n=288)$ in the database of the Institute of Forensic Medicine in Milan, Italy, over 27 years (1993-2019). In our study, in the majority of cases, victims were males and older adults, with a mean age of 66.6 years, reaching the maximum number of cases in the decade between 71 and 80 years. Decades between 25 and 41 years old were the least represented. These findings are consistent with the data reported in a recent literature review [45]. In our cases, we have not recorded suicides of pediatric cancer patients, although this phenomenon is well documented in the literature even in cancers with long-term survival [46]. However, one of the inclusion criteria of our work was that all subjects must have undergone an autopsy. In fact, the performance of autopsies on minors (children and adolescents) is a practice that may not be routinely performed or tends to be discouraged. It is too often a procedure considered "inappropriate" as it maims the innocence of younger victims according to certain cultures [47].

With respect to the specific viscera, which were the site of tumor development, lungs were the most prevalent, followed by the prostate, breast and colon, similarly to what is reported by other international studies [48]. To better understand our data, we took into consideration the prevalence of cancers in the general Italian population. We found that, in descending order, lung, breast, prostate and colon cancers are the most frequently diagnosed in the general population [49]. These data are entirely consistent with the prevalence of cancers recorded in our analysis. The only discrepancy we observed concerned a higher prevalence of prostate cancer compared to breast cancer. However, this is a completely explainable finding considering the higher number of male victims compared to the female ones in our case series (ratio of 2.3 to 1 ).

In addition to malignant neoplasm, the majority of the subjects (64\%) were also affected by other diseases, particularly depression $(51 \%)$, which is notoriously more present in cancer patients than in the general population [5]. Such findings were coherent with the data reported in the literature [32]. As for depression, it emerged that only 67 (46\%) out 
of the total of 146 subjects were in specific pharmacological treatment. This discrepancy can only be minimally explained by a lack of clinical and health information relating to the enrolled victims. Conversely, it emphasizes the fact that most likely greater attention should be paid to screening of depressive symptoms and the treatment of this pathology, especially in a category of subjects at high risk of suicide, such as cancer patients. Furthermore, in such patients, the management of depression and suicide prevention strategies should be modulated based on the illness trajectory. Thus, the literature suggests that different prevention strategies may be developed with respect to three different periods within the disease course. The first would target patients who have recently been diagnosed with cancer. The second one would be focused on cancer patients under treatment or cancer survivors, who may suffer from functional loss due to invasive anti-cancer treatments. The last one would be for patients with advanced cancer [50,51]. Studies have consistently shown that not only major depression and emotional distress but also substantial pain, impaired physical functioning and the loss of autonomy and independence are clinical factors most commonly associated with suicidal thoughts in these patients [52-56]. The preponderant role of depression is supported by the fact that in cancer patients the risk of suicide tends to disappear after an adequate treatment of depression [50,51]. Therefore, it is conceivable that adequate antidepressant therapy could have prevented suicide in at least part of the cancer patients enrolled in our study. It is usually thought that only cancers with a poor prognosis have a greater impact on the quality of life. However, it is important to point out that even curable cancers, such as testicular germ cell tumors, or those with long-term survival, such as low-grade gliomas, can severely affect patients' quality of life or self-image and cause psychiatric stress, which can result in suicide [46].

As for the method of suicide, violent suicides (87\%) prevailed by far compared to non-violent ones $(13 \%)$. The male gender was far more involved in violent suicides $(72 \%)$. As for non-violent suicides, the two genders were almost overlapping, with a very slight male prevalence equal to $51.5 \%$ against $48.5 \%$. Only for one detrimental modality, i.e., the chemical one, was a greater involvement of the female sex observed.

By comparing anatomical sites affected by cancer with the applied suicide method, the most observed detrimental modality was the fall from height, regardless of the involved body area. Suicidal gunshots were mostly performed by subjects affected by lung and prostate cancer. On the other hand, hanging was mostly preferred by subjects suffering from lung and colon cancer. Among non-violent suicides, the chemical modality prevailed, especially in patients affected by breast cancer. With respect to chemical injury, the suicidal intake of chemical substances, considered as a "sweet and painless death", could have been easily applied by subjects in possession of many categories of medications (analgesics, morphine and benzodiazepines); however, it concerned only a minority of all cases enrolled in the study. In particular, we did not record any victim who died from an opioid drug overdose. This finding is in contrast to what has been reported in the literature, especially in countries such as the United States, where the phenomena of opioid dependence and abuse are mainly related to their non-medical use [57]. In Italy, the use of opioid analgesics remains far lower than in Northern Europe and the United States. In addition, numerous efforts have been made to ensure that physicians and pharmacists exercise greater vigilance in prescribing or dispensing opioid drug to at-risk patients [58]. For these reasons, most likely in cancer patients, the use of opioid drugs remains more restricted to medical use only. In general, when examining the violent or non-violent nature of the suicidal modality, it appears to be explained by its relationship to the gender of the victims rather than to the site of the tumor.

Most likely, the choice of the largest number of cancer patients to die by suicide by falling from a height was dictated by some intrinsic characteristics of such a detrimental modality, such as the simplicity of performance and the easy accessibility to windows and balconies; moreover, it does not require subject's familiarity and practicality of any tool and, above all, it lends itself very well to an impulsive gesture. On the contrary, all other suicide methods imply different-degree programming. Such a hypothesis is also supported by the 
fact that almost all cancer patients who die by suicide in the hospital setting decided to resort to falling from a height. Although we are not aware of the reason why such patients were in the hospital the day they died, they had probably visited for problems related to their neoplastic pathology. Considering these results, restricting access to suicide means of places in general hospitals that may become hotspots must be considered. On the other hand, compared to the majority of cancer patients who died by suicide after an apparently impulsive gesture, a minority of them seemed to have carried out planned suicides. Among such subjects, some resorted to different detrimental modalities simultaneously or in chronological succession. The purpose was to avoid a possible ineffectiveness of one of the chosen mechanisms and achieve a guaranteed fatal outcome testifying their determination to die $[39,41]$. In relation to emerged data, for the sake of completeness, we emphasize that, in Italy, currently, there is still no legislation that regulates physician-assisted suicide, unlike many other European countries.

\section{Conclusions}

Although the carried-out analysis is of a descriptive nature, our data allowed outlining possible "typical" characteristics of cancer patients who died by suicide: they are mostly elderly men that are often depressed and affected by a malignant neoplasm with predominantly thoracic or abdominal localization (lung, breast, colon and prostate). They usually resort to a violent suicide method, thus being able to configure cases of challenging classification regarding the modality of death for forensic pathologists. In view of the documented link between cancer patients and violent suicide, forensic pathologists should be aware of the high chance to find even very destructive injuries in these victims without necessarily implying a method other than suicide. In the possibility of examining in detail both the cause of death and the modalities of suicide of oncological patients lies the precious and alternative contribution that forensic pathology can offer to shed further light on this phenomenon. It is, in fact, information of exclusive autopsy-forensic origin. In this sense, autopsy stands as an indispensable means of protection of public health, and prevention for the entire community. Indeed, the considerations that emerged from this descriptive analysis could certainly have important repercussions. They could serve both to raise public awareness on the phenomenon of suicide in cancer patients and help deepen and improve the clinical approach of psychological, psychiatric and oncological services in identifying adequate prevention tools and in offering patients effective cancer interventions specifically targeted at suicide risk.

\section{Limitations}

We acknowledge that anamnestic data of the victims enrolled in this retrospective study may be incomplete in some of their parts, especially with respect to cancer patients degree of physical, social and emotional suffering, as well as their feelings with respect to the oncological pathology they were suffering from. Further consideration is the lack of comparison with a cohort of suicides of non-oncological subjects. This aspect is absent because we conducted descriptive analysis of the phenomenon of suicide in cancer patients from an autopsy-forensic point of view, although such a comparison could represent a prospect for future investigation. Similarly, the possibility of conducting a study of suicides in patients first diagnosed with cancer at autopsy could also be an interesting research development in order to investigate possible correlations between systemic inflammatory mechanisms, neoplasia, depression and suicide.

Author Contributions: Conceptualization, G.G. and S.T.; methodology, G.G. and S.T.; validation, R.C. and R.Z.; formal analysis, G.G. and S.T.; investigation, G.G., S.T. and R.C.; data curation, R.C.; writing—original draft preparation, G.G. and S.T.; writing—review and editing, S.T. and R.C.; supervision, R.Z.; project administration, R.Z. All authors have read and agreed to the published version of the manuscript.

Funding: This research received no external funding. 
Institutional Review Board Statement: The study was conducted according to the guidelines of the Declaration of Helsinki. Ethical review and approval were waived for this study, since all the subjects involved in this study underwent judicial autopsy at the Institute of Legal Medicine of Milan in order to identify the cause of death. Data collecting, sampling and subsequent forensic analysis were authorized by the inquiring magistrate. In accordance with Italian law, ethical approval is not required in these cases; however, the anonymity of subjects must be guaranteed.

Informed Consent Statement: Data collecting, sampling and subsequent forensic analysis were authorized by the inquiring magistrate. In accordance with Italian law, informed consent statement is not required in these cases; however, the anonymity of subjects must be guaranteed.

Data Availability Statement: All the data have been reported in the manuscript.

Conflicts of Interest: The authors declare no conflict of interest.

\section{References}

1. World Health Organization. Suicide Data. Available online: https://www.who.int/teams/mental-health-and-substance-use/ suicide-data (accessed on 8 November 2021).

2. World Health Organization. Cancer. Available online: https://www.who.int/news-room/fact-sheets/detail/cancer (accessed on 8 November 2021).

3. Dwyer, J.; Hiscock, R.; O'Callaghan, C.; Taylor, K.; Ross, M.; Bugeja, L.; Philip, J. Characteristics of patients with cancer who die by suicide: Coronial case series in an Australian state. Psychooncology 2019, 28, 2195-2200. [CrossRef] [PubMed]

4. Schneider, K.L.; Shenassa, E. Correlates of suicide ideation in a population-based sample of cancer patients. J. Psychosoc. Oncol. 2008, 26, 49-62. [CrossRef] [PubMed]

5. Du, L.; Shi, H.Y.; Yu, H.R.; Liu, X.M.; Jin, X.H.; Qian, Y.; Fu, X.L.; Song, Y.P.; Cai, J.Y.; Chen, H.L. Incidence of suicide death in patients with cancer: A systematic review and meta-analysis. J. Affect. Disord. 2020, 276, 711-719. [CrossRef] [PubMed]

6. Ravaioli, A.; Crocetti, E.; Mancini, S.; Baldacchini, F.; Giuliani, O.; Vattiato, R.; Bucchi, L.; Falcini, F. Suicide death among cancer patients: New data from northern Italy, systematic review of the last 22 years and meta-analysis. Eur. J. Cancer 2020, 125, 104-113. [CrossRef]

7. Amiri, S.; Behnezhad, S. Cancer Diagnosis and Suicide Mortality: A Systematic Review and Meta-Analysis. Arch. Suicide Res. 2020, 24, S94-S112. [CrossRef]

8. Semple, C.J.; Sullivan, K.; Dunwoody, L.; Kernohan, W.G. Psychosocial interventions for patients with head and neck cancer: Past, present, and future. Cancer Nurs. 2004, 27, 434-441. [CrossRef]

9. Anderson, C.; Park, E.M.; Rosenstein, D.L.; Nichols, H.B. Suicide rates among patients with cancers of the digestive system. Psychooncology 2018, 27, 2274-2280. [CrossRef] [PubMed]

10. Rahouma, M.; Kamel, M.; Abouarab, A.; Eldessouki, I.; Nasar, A.; Harrison, S.; Lee, B.; Shostak, E.; Morris, J.; Stiles, B.; et al. Lung cancer patients have the highest malignancy-associated suicide rate in USA: A population-based analysis. Ecancermedicalscience 2018, 12, 859. [CrossRef]

11. Guo, Z.; Gan, S.; Li, Y.; Gu, C.; Xiang, S.; Zhou, J.; Gong, L.; Chan, F.L.; Wang, S. Incidence and risk factors of suicide after a prostate cancer diagnosis: A meta-analysis of observational studies. Prostate Cancer Prostatic Dis. 2018, 21, 499-508. [CrossRef]

12. Fox, B.H.; Stanek III, E.J.; Boyd, S.C.; Flannery, J.T. Suicide rates among cancer patients in Connecticut. J. Chronic Dis. 1982, 35, 89-100. [CrossRef]

13. Anguiano, L.; Mayer, D.K.; Piven, M.L.; Rosenstein, D. A literature review of suicide in cancer patients. Cancer Nurs. 2012, 35, E14-E26. [CrossRef] [PubMed]

14. Fegg, M.; Kraus, S.; Graw, M.; Bausewein, C. Physical compared to mental diseases as reasons for committing suicide: A retrospective study. BMC Palliat. Care. 2016, 15, 14. [CrossRef]

15. Lin, P.H.; Liao, S.C.; Chen, I.M.; Kuo, P.H.; Shan, J.C.; Lee, M.B.; Chen, W.L. Impact of universal health coverage on suicide risk in newly diagnosed cancer patients: Population-based cohort study from 1985 to 2007 in Taiwan. Psychooncology 2017, 26, 1852-1859. [CrossRef]

16. Vyssoki, B.; Gleiss, A.; Rockett, I.R.; Hackl, M.; Leitner, B.; Sonneck, G.; Kapusta, N.D. Suicide among 915,303 Austrian cancer patients: Who is at risk? J. Affect. Disord. 2015, 175, 287-291. [CrossRef]

17. Allebeck, P.; Bolund, C.; Ringbäck, G. Increased suicide rate in cancer patients. A cohort study based on the Swedish CancerEnvironment Register. J. Clin. Epidemiol. 1989, 42, 611-616. [CrossRef]

18. Fang, F.; Fall, K.; Mittleman, M.A.; Sparén, P.; Ye, W.; Adami, H.O.; Valdimarsdóttir, U. Suicide and cardiovascular death after a cancer diagnosis. N. J. Med. 2012, 366, 1310-1318. [CrossRef]

19. Crocetti, E.; Arniani, S.; Acciai, S.; Barchielli, A.; Buiatti, E. High suicide mortality soon after diagnosis among cancer patients in central Italy. Br. J. Cancer 1998, 77, 1194-1196. [CrossRef]

20. Nasseri, K.; Mills, P.K.; Mirshahidi, H.R.; Moulton, L.H. Suicide in cancer patients in California, 1997-2006. Arch. Suicide Res. 2012, 16, 324-333. [CrossRef] 
21. Ward, K.K.; Roncancio, A.M.; Plaxe, S.C. Women with gynecologic malignancies have a greater incidence of suicide than women with other cancer types. Suicide Life Threat. Behav. 2013, 43, 109-115. [CrossRef] [PubMed]

22. Misono, S.; Weiss, N.S.; Fann, J.R.; Redman, M.; Yueh, B. Incidence of suicide in persons with cancer. J. Clin. Oncol. 2008, 26, 4731-4738. [CrossRef] [PubMed]

23. Harris, E.C.; Barraclough, B. Suicide as an outcome for mental disorders. A meta-analysis. Br. J. Psychiatry 1997, 170, 205-228. [CrossRef]

24. Ullman, K. Cancer survivorship gains importance. J. Natl. Cancer Inst. 2014, 106, djt450. [CrossRef]

25. Bellini, M.; Capannini, D. Increased suicide risk in cancer patients. Minerva Psichiatr. 1994, 35, $175-186$.

26. Allemani, C.; Weir, H.K.; Carreira, H.; Harewood, R.; Spika, D.; Wang, X.S.; Bannon, F.; Ahn, J.V.; Johnson, C.J.; Bonaventure, A.; et al. Global surveillance of cancer survival 1995-2009: Analysis of individual data for 25,676,887 patients from 279 population-based registries in 67 countries (CONCORD-2). Lancet 2015, 385, 977-1010. [CrossRef]

27. Breitbart, W.; Rosenfeld, B.; Pessin, H.; Kaim, M.; Funesti-Esch, J.; Galietta, M.; Nelson, C.J.; Brescia, R. Depression, hopelessness, and desire for hastened death in terminally ill patients with cancer. JAMA 2000, 284, 2907-2911. [CrossRef]

28. Louhivuori, K.A.; Hakama, M. Risk of suicide among cancer patients. Am. J. Epidemiol. 1979, 109, 59-65. [CrossRef] [PubMed]

29. Diaz-Frutos, D.; Baca-Garcia, E.; Mahillo-Fernandez, I.; Garcia-Foncillas, J.; Lopez-Castroman, J. Suicide ideation among oncologic patients in a Spanish ward. Psychol. Health Med. 2016, 21, 261-271. [CrossRef] [PubMed]

30. Sperner-Unterweger, B. Depression in cancer patients. Wien Med. Wochenschr. 2015, 165, 297-303. [CrossRef]

31. Brunckhorst, O.; Hashemi, S.; Martin, A.; George, G.; Van Hemelrijck, M.; Dasgupta, P.; Stewart, R.; Ahmed, K. Depression, anxiety, and suicidality in patients with prostate cancer: A systematic review and meta-analysis of observational studies. Prostate Cancer Prostatic Dis. 2021, 24, 281-289. [CrossRef]

32. De la Grandmaison, G.L.; Watier, L.; Cavard, S.; Charlier, P. Are suicide rates higher in the cancer population? An investigation using forensic autopsy data. Med. Hypotheses 2014, 82, 16-19. [CrossRef]

33. Juurlink, D.N.; Herrmann, N.; Szalai, J.P.; Kopp, A.; Redelmeier, D.A. Medical illness and the risk of suicide in the elderly. Arch Intern. Med. 2004, 164, 1179-1184. [CrossRef] [PubMed]

34. Llorente, M.D.; Burke, M.; Gregory, G.R.; Bosworth, H.B.; Grambow, S.C.; Horner, R.D.; Golden, A.; Olsen, E.J. Prostate cancer: A significant risk factor for late-life suicide. Am. J. Geriatr. Psychiatry 2005, 13, 195-201. [CrossRef] [PubMed]

35. Conwell, Y.; Duberstein, P.R.; Hirsch, J.K.; Conner, K.R.; Eberly, S.; Caine, E.D. Health status and suicide in the second half of life. Int. J. Geriatr. Psychiatry 2010, 25, 371-379. [CrossRef] [PubMed]

36. Fall, K.; Fang, F.; Mucci, L.A.; Ye, W.; Andrén, O.; Johansson, J.E.; Andersson, S.O.; Sparén, P.; Klein, G.; Stampfer, M.; et al. Immediate risk for cardiovascular events and suicide following a prostate cancer diagnosis: Prospective cohort study. PLoS Med. 2009, 6, e1000197. [CrossRef] [PubMed]

37. Träskman, L.; Asberg, M.; Bertilsson, L.; Sjöstrand, L. Monoamine metabolites in CSF and suicidal behavior. Arch. Gen. Psychiatry 1981, 38, 631-636. [CrossRef]

38. Ludwig, B.; Dwivedi, Y. The concept of violent suicide, its underlying trait and neurobiology: A critical perspective. Eur. Neuropsychopharmacol. 2018, 28, 243-251. [CrossRef] [PubMed]

39. Gentile, G.; Galante, N.; Tambuzzi, S.; Zoja, R. A forensic analysis on 53 cases of complex suicides and one complicated assessed at the Bureau of Legal Medicine of Milan (Italy). Forensic Sci. Int. 2021, 319, 110662. [CrossRef]

40. Altun, G. Planned complex suicide: Report of three cases. Forensic Sci. Int. 2006, 157, 83-86. [CrossRef]

41. Racette, S.; Sauvageau, A. Planned and unplanned complex suicides: A 5-year retrospective study. J. Forensic Sci. 2007, 52, 449-452. [CrossRef]

42. Gentile, G.; Bianchi, M.; Boracchi, M.; Goj, C.; Tambuzzi, S.; Zoja, R. Forensic pathological considerations of a unique case of "complicated suicide". J. Forensic Sci. 2020, 65, 2184-2187. [CrossRef]

43. Töro, K.; Pollak, S. Complex suicide versus complicated suicide. Forensic Sci. Int. 2009, 184, 6-9. [CrossRef]

44. Saukko, P.; Knight, B. Burns and scalds. In Knight's Forensic Pathology; Saukko, P., Knight, B., Eds.; Hodder Arnold: London, UK, 2004; pp. 312-323.

45. Calati, R.; Filipponi, C.; Mansi, W.; Casu, D.; Peviani, G.; Gentile, G.; Tambuzzi, S.; Zoja, R.; Fornaro, M.; Lopez-Castroman, J.; et al. Cancer diagnosis and suicide outcomes: Umbrella review and methodological considerations. J. Affect. Disord. 2021, 295, 1201-1214. [CrossRef]

46. Upadhyaya, S.A.; Ghazwani, Y.; Wu, S.; Broniscer, A.; Boop, F.A.; Gajjar, A.; Qaddoumi, I. Mortality in children with low-grade glioma or glioneuronal tumors: A single-institution study. Pediatr. Blood Cancer. 2018, 65, e26717. [CrossRef]

47. Sauvageau, A.; Racette, S. Child and adolescent victims in forensic autopsy: A 5-year retrospective study. J. Forensic Sci. 2008, 53, 699-702. [CrossRef]

48. Zaorsky, N.G.; Zhang, Y.; Tuanquin, L.; Bluethmann, S.M.; Park, H.S.; Chinchilli, V.M. Suicide among cancer patients. Nat. Commun. 2019, 10, 207. [CrossRef] [PubMed]

49. Akechi, T.; Kugaya, A.; Okamura, H.; Nakano, T.; Okuyama, T.; Mikami, I.; Shima, Y.; Yamawaki, S.; Uchitomi, Y. Suicidal thoughts in cancer patients: Clinical experience in psycho-oncology. Psychiatry Clin. Neurosci. 1999, 53, 569-573. [CrossRef] [PubMed]

50. AIOM. I Numeri del Cancro in Italia 2021; Intermedia Editore: Brescia, Italy, 2021; pp. 1-177.

51. Akechi, T. Suicide prevention among patients with cancer. Gen. Hosp. Psychiatry 2020, 64, 119-120. [CrossRef] 
52. Henriksson, M.M.; Isometsä, E.T.; Hietanen, P.S.; Aro, H.M.; Lönnqvist, J.K. Mental disorders in cancer suicides. J. Affect. Disord. 1995, 36, 11-20. [CrossRef]

53. Akechi, T.; Okamura, H.; Yamawaki, S.; Uchitomi, Y. Why do some cancer patients with depression desire an early death and others do not? Psychosomatics 2001, 42, 141-145. [CrossRef] [PubMed]

54. Filiberti, A.; Ripamonti, C.; Totis, A.; Ventafridda, V.; De Conno, F.; Contiero, P.; Tamburini, M. Characteristics of terminal cancer patients who committed suicide during a home palliative care program. J. Pain Symptom Manag. 2001, 22, 544-553. [CrossRef]

55. Smith, M.T.; Edwards, R.R.; Robinson, R.C.; Dworkin, R.H. Suicidal ideation, plans, and attempts in chronic pain patients: Factors associated with increased risk. Pain 2004, 111, 201-208. [CrossRef] [PubMed]

56. Walker, J.; Waters, R.A.; Murray, G.; Swanson, H.; Hibberd, C.J.; Rush, R.W.; Storey, D.L.; Strong, V.A.; Fallon, M.T.; Wall, L.R.; et al. Better off dead: Suicidal thoughts in cancer patients. J. Clin. Oncol. 2008, 26, 4725-4730. [CrossRef]

57. Sinyor, M.; Howlett, A.; Cheung, A.H.; Schaffer, A. Substances used in completed suicide by overdose in Toronto: An observational study of coroner's data. Can. J. Psychiatry 2012, 57, 184-191. [CrossRef] [PubMed]

58. Fornasari, D.; Gerra, G.; Maione, S.; Mannaioni, G.; Mugelli, A.; Parolaro, D.; Romualdi, P.; Sacerdote, P. Trattamento del dolore cronico in Italia: Appropriatezza terapeutica con oppiacei e timore di addiction: Situazione italiana vs USA. Quotidianosanità 2019, $I, 1-20$. 